\title{
Television and/as testimony in the Jimmy Savile case
}

\section{Introduction}

As I was writing this article in autumn 2017, allegations of sexual harassment and rape against Hollywood mogul Harvey Weinstein emerged (Kantor and Twohey, 2017). This article focuses on television coverage of sexual abuse revelations involving another celebrity perpetrator, Jimmy Savile: TV presenter, DJ and charity fundraiser. As Emma Thompson noted, the Weinstein allegations echo this earlier scandal and highlight the extent to which sexism and sexual harassment are endemic to the screen industries. (1) For the purposes of this article, there are four parallels of significance: the link between (alleged) perpetrators' abusive practices and their media careers; the identification of multiple victims and other perpetrators; the fact that these allegations were already known in certain circles; and the sense that Savile and Weinstein were always already outsiders in the industries which made them. A brief discussion of these points will set up themes to be explored in this article: the Savile case as a story about and on television; the televisual construction of victim/survivor believability over time; challenges in representing sexual abuse perpetrators; and what the case has meant for the televisual archive.

As the Weinstein story unfolded, it quickly became apparent that Weinstein's and others' successful careers in the screen industries were not indivisible from their (alleged) sexual harassment and abuse of women, men and children. Their screen careers gave them the power to abuse and provided a rationale for abuse: part of the business of making movies, even a sign of creative genius, legitimated by the on-screen results (Hardie, 2017). Their success and power provided insulation against accusation, making it difficult for victim/survivors to come forward whilst the (cultural and monetary) value of their screen work meant many were willing to ignore the evidence which was already - to a greater or lesser extent - in the public domain. Relative to Weinstein's Oscar successes, Savile's light entertainment output may seem less critically significant: one of the reasons, perhaps, that the case has attracted little attention within Television Studies. However, Savile's association with music and children's television meant that many viewers remained emotionally invested in Savile, a theme I return to in my conclusion. How we - as viewers and media scholars - deal with these men's output and legacy in light of their (alleged) crimes is a live question (e.g. Parkinson, 2017; Silverstein, 2017; Brooks, 2017).

Savile was dead when the allegations against him finally stuck, arguably making these questions easier to deal with. Given Savile abused victims on BBC premises, using his shows to facilitate access to vulnerable youngsters (Smith, 2016), his output is now understood to be indivisible from the abuse. As Rowan Aust and Amy Holdsworth (2017) have explored, among the many problems this has created for the $B B C$ is how to deal with his enduring presence in the archive (also Aust, 2018). This relates to the continuing value of Top of the Pops (BBC, 1964-2006) for reruns and nostalgia programming - Aust and Holdsworth's primary concern - but also to how the stories of his abuse can be told televisually: my focus in this article.

The second point of connection between the Weinstein and Savile moments is the emergence of multiple victim/survivors and perpetrators. As millions of women globally 
declared \#MeToo on social media in autumn 2017, I was reminded of Liz Kelly's (1988) influential theorisation of women's experiences of sexual violence lying on a continuum. The continuum allows us to see connections between different experiences and the ways in which, for victim/survivors, sexual harassment and abuse are experienced cumulatively across a lifetime. As host Jo Brand put it on Have I Got News For You (3 November 2017):

I know it's not high level, but it doesn't have to be high level for women to feel under siege in somewhere like the House of Commons. And actually, for women, if you're constantly being harassed, even in a small way, that builds up. And that wears you down.(2)

Brand's comments - and Kelly's research - allow us to understand how apparently innocuous acts (a hand on a knee) are linked to acts more widely recognised as serious, and criminal (such as rape). They are linked in women's experiences, in the way one creates the context for the other, and as both express male power through sexualised dominance.

Yet, if the \#MeToo moment has demonstrated the collective power of women's (men's and children's) testimony, it has also highlighted that some voices matter more than others. The campaign went global after American actor Alyssa Milano encouraged her followers to use the hashtag if they had experienced sexual harassment. However, its origins are credited to Tarana Burke for whom 'MeToo' was a response to hearing stories of sexual abuse from young women of colour.(3) For the media (and others) to pay attention to these allegations, they have to first believe that victim/survivors matter. Feminist media studies has long documented the ways in which gender, race, age and class shape which victims count (Boyle, 2005). And counting has a double meaning here: women only matter in multiples (Boyle, 2017).

In the Savile case, it is his assaults on children which have discursively dominated, such that the gendered power dynamics underpinning the case have not been well interrogated in media coverage or in academic scholarship (Boyle, 2017). Whilst Emma Thompson's interview, mentioned above, points to cultural and institutional sexism as the 'conducive context' (Kelly, 2005) for both men's behaviour, it is reflective of the way that Savile is now retrofitted as a predatory paedophile whose crimes are understood through the lens of celebrity and power - but not gender -that this connection is not more widely made in UK reporting of the Weinstein case. (4)

The third thing which the Savile and Weinstein cases have in common is that their abusive behaviour was widely known but ignored and even condoned. In both cases, women's attempts to be heard when they spoke about abuse had been continually frustrated over years, even decades. Savile himself jokingly acknowledged his abusive behaviour in his lifetime and it was often conducted in plain sight of witnesses and even television cameras (Davies, 2014; Cross, 2016; Boyle, 2017). Whilst the most serious allegations were less widely known, the tacit approval of 'everyday sexism' (Bates, 2014) contributed to a 'conducive context' (Kelly, 2005) for more serious violence.

Yet, once the stories of abuse were finally recognised as abuse, there was - in both cases - a fairly swift construction of Savile and Weinstein as monstrous figures although, as I will 
demonstrate, this did not necessarily extend to the more nuanced portrayals of Savile in television documentaries about his crimes. The two men, although unquestionably powerful media figures, never embodied certain norms of their industry - including physically and aesthetically - and so could more easily be 'othered' when the abuse narratives were finally recognised as such (Aust, 2018). The 'prettier' men of Hollywood - and the 'classier' men of television - who have also been named as abusers in this period have not, on the whole, been treated in the same way. There is further work to be done in comparing the visual representation of Savile and Weinstein with men like Kevin Spacey, Johnny Depp or Dustin Hoffman, or in a British TV context, with convicted celebrity sex offenders including Max Clifford, Stuart Hall and Rolf Harris. This article argues against an aesthetics of the monstrous and insists that Savile should still be part of our television landscape, albeit in modified ways, if we want to understand his crimes.

At the heart of both cases, then, are questions of representation and representability: of sexual assault, perpetrators and victim/survivors. In this article, I explore how television documentaries about the Savile case negotiate this terrain. I begin with a brief outline of how the story finally broke, before considering how television dealt with Savile's televisual presence and the - previously unknown - victim/survivors, before returning to the wider lessons we can learn from this.

\section{The Savile case}

On 3 October 2012, ITV's documentary series Exposure (2011-) broadcast The Other Side of Jimmy Savile, alleging that Savile was a predatory sex offender. Although allegations against Savile had been around for some time - and these specific allegations were first reported in the UK nearly 10 months earlier- it wasn't until Exposure that they were widely taken seriously. In the run-up to the broadcast - and more dramatically following it - a picture emerged of an abusive career spanning five decades, implicating the BBC, National Health Service and police. (5) At the heart of the story was the BBC's decision to shelve an earlier investigation into Savile by its flagship current affairs programme Newsnight (BBC2, 1980-) and, instead, broadcast a range of tributes to Savile in the months following his October 2011 death. (6) As result, this quickly became a story about only about a television personality, but rather about television more widely: the shelved Newsnight investigation, ITV's Exposure documentary and subsequent investigations into BBC working cultures (Pollard, 2012; Smith, 2016). The power of television in creating conditions for victim/survivors to come forward also became a central theme.

Existing scholarship on Savile and television has focused on the archive (Aust and Holdsworth, 2017; Aust, 2018) and Savile's ghostly presence (Wheatley, 2017) whilst work specifically on the abuse revelations has focused on press coverage (Greer and McLaughlin 2013, 2015; Furedi 2013, 2015; Boyle, 2017). This article takes a different focus, examining documentaries about the Savile case shown on Britain's main television channels between October 2012 and October 2016. The programmes are:

- Exposure: The Other Side of Jimmy Savile (ITV, 3 October 2012)

- Jimmy Savile - What the BBC Knew: A Panorama Special (BBC1, 22 October 2012) 
- Exposure Update: The Jimmy Savile Investigation (ITV, 21 November 2012)

- Panorama - After Savile: No More Secrets? (BBC1, 4 November 2013)

- Panorama - Savile: The Power to Abuse (BBC1, 2 June 2014)

- Britain's Worst Crimes: Jimmy Savile (Channel 5, 18 November 2015)

- Abused: The Untold Story (BBC1, 11 April 2016)

- Louis Theroux: Savile (BBC2, 2 October 2016)

These documentaries are discussed alongside television coverage of the initial allegations, and a Crimewatch Special, Catching the Abusers (27 February 2017), which focuses on nonrecent child sexual abuse and includes testimony about Savile. There has been an explosion of both documentary (7) and drama (8) programming tackling child sexual abuse in this period and Savile has been positioned within this broader context as a child abuser. The repeated narrative emphasis on child sexual abuse - even although a number of the documentaries include testimonies from women abused as adults - means that there is a missed opportunity to understand the links between men's abuse of adult women and children. (9) Male narrators, investigators, presenters, experts, witnesses and supporters play a key role across all the documentaries in legitimating and interpreting women's accounts. Notably, there are no feminist organisations or commentators used in any of the documentaries. These limitations need to be kept in mind, not least as my focus on victim/survivors in this article suggests an otherwise more progressive reading of televisual treatments of the case.

The documentaries explicitly build on one another and, indeed, on previous accounts of Savile, notably Theroux's When Louis Met... Jimmy (BBC2, 13 April 2000). This results in considerable repetition - including of victim/survivor testimony - which works to create a new televisual archive, heightening the sense that these documentaries are fundamentally about television, as well as being television. It is the very ordinariness of television's repetitions which allows for Savile's legacy to be so substantially reworked. Yet, this depends upon the visibility and legibility of victim/survivors: something that is rarely possible or desirable in relation to sexual violence and is made more difficult in the absence of explicitly feminist expert commentary.

Victim/survivors who have spoken publicly have described the process of testifying as, at times, a revictimisation (Jordan, 2013; Ward, 2016). How to describe women who experience sexual violence has been a feminist concern for decades. We need a language which acknowledges what has been done to women whilst not allowing the assault to entirely define who 'they' are or negate their agency (Jordan, 2013). Feminists have also challenged the notion that there is a one-way journey from victimisation to survival, noting instead the survival strategies which women deploy during an attack (e.g. to minimise physical harm or dissociate from what is happening) and the ways in which the effects of abuse can be experienced more or less intensely across a lifetime (Kelly, Burton and Reagan, 1996; Brison, 2003; Jordan, 2013). Jan Jordan (2013: 54) memorably describes this as a 'series of survivings', a phrase which resonates in the televisual testifying of victim/survivors of Savile. Indeed, many of these women (and, later, men), mention how living with Savile's television presence provided a constant reminder of the abuse and the impossibility of reporting it. Yet, it is also important to note that - as more recently with \#MeToo - highly 
publicised cases, whilst re-traumatising for victim/survivors, can also enable others to seek help and justice. (10)

This is only one of the difficulties inherent in representing abuse. As Janet Walker (2005), Liz Kelly (1996), Jenny Kitzinger (1999), Louise Armstrong (1996) and I (Boyle, 2009) have variously explored, there is a tension between a kind of hypervisibility or media 'noise' around child sexual abuse on one hand, and its apparent (un)representability on the other. Child sexual abuse is constructed as so traumatic that it renders victim/survivors speechless, meaning that the authenticity of victim/survivors who are willing/able to speak publicly is often immediately in doubt (Boyle, 2009: 182). Feminist analyses of men's sexual violence against adult women similarly point to the ways in which popular constructions of rape - as the worst possible thing that could happen to a woman - create constraints around women's speech and impact its believability (Jordan, 2011). A woman who has not only survived what should have rendered her silent, but has survived to speak of that experience is herself deemed suspect (Jordan, 2011). This is exacerbated when the perpetrator is a man who is - or appears to be - widely revered.

Certainly, many of Savile's accusers had tried to make their stories heard during Savile's lifetime. Indeed, even when the specific allegations detailed in Exposure were first reported, the story did not ignite and Savile's standing remained untarnished (Boyle, 2017). In the first days of the Exposure story, there was some pushback against victim/survivors with their motivations, credibility and even sanity being questioned (Ward, 2016). However, the televisual testimony of victims/survivors did not - on the whole - go through the torturous negotiations around credibility identified in other work discussed above. Indeed, beyond the first days of the Exposure story - when Savile's family and friends occasionally challenged the emerging account - the credibility of victim/survivors was largely not up for debate, although their accounts were certainly scrutinised.

In the next section, my focus is on Savile himself: the dominant image of him before the revelations, and the televisual representations of him as they emerge. How does the selection, repetition and altering of archive footage shape the meaning of the accusations, and how does this change over time? Whilst there is no straight-forward linear narrative here, there is a re-evaluation of Savile's place in the television archive which hinges not only on his value (or toxicity) but more centrally on what that archive does (and does not) reveal. As the Savile case accrues an archive of its own, in which victim/survivor testimonies feature prominently, Savile's shows recede into the background. How, then, are the victim/survivor testimonies staged, repeated and referenced? When are they seen and heard? At the heart of this article is a concern with the (un)representability of (child) sexual abuse and the contested position of the abuser in the televisual archive. The issues here are complex and a balance has to be struck - differently at different stages in the development of the story between evidence and anonymity, celebrity and accountability, victim/survivor silence and speech.

\section{Now you see him. Now you don't.}

After his death in October 2011, Savile remained a television presence. Whilst his archival value was mined most obviously in tribute shows and ongoing re-runs of Top of the Pops 
(BBC, 1964-2006), he was more ubiquitous than this suggests. In the weeks before Exposure, for example, archival footage of Savile was used in Idris Elba's How Clubbing Changed the World (Channel 4, 24 August 2012), Tom Jones at the BBC (BBC 4, 21 September 2012), The Story of Light Entertainment (BBC4, 30 September 2012) and The Age of the Train (BBC4, 14 September 2012). This by no means exhaustive list is a useful reminder of his currency at the time of the allegations.

Existing commentaries on the Savile case have repeatedly pointed to the way in which Savile's hypervisibility was an alibi for abuses conducted 'in plain sight', yet invisible as abuse (e.g. Boyle, 2017; Cross, 2016; Davies, 2014). Given what we now know, the onscreen visibility of behaviour such as unwanted sexual touching can seem painfully obvious. However, part of the reason the abuse was not entirely legible prior to Exposure was because of the resilience of Savile's counter-narrative.

Indeed, although my instinct in rewatching television news coverage surrounding Exposure was to recoil from the extensive use of archival footage of Savile himself, the accumulation of this material contextualises and adds credibility to the women's testimonies.

Comparatively little of the footage used shows an older Savile (he was 84 when he died), emphasising instead his televisual heyday and anchoring the women's testimonies in time (the initial revelations largely relating to the 1960s, 1970s and early 1980s). The archival footage also supports the women's reasoning for not speaking out earlier, or not being believed if they did so: Savile was simply too ubiquitous and highly-regarded. The relentless repetitions replicate for viewers Savile's inescapable familiarity. Yet, as acknowledged above, the archival footage may have prolonged the suffering of victim/survivors by extending Savile's ubiquity beyond death. Televisual evidence deceives, harms and, yet, through recontextualisation, reveals.

The opening of Exposure demonstrates these points. It begins with presenter Mark Williams-Thomas outlining, in voiceover, Savile's status in life before introducing the allegations. The voiceover is accompanied by a montage of video clips and photographs of Savile which provides evidence of Williams-Thomas' narration - we hear Savile was a friend of prime ministers, we see him with Margaret Thatcher. But they do something more. From an opening sequence in which Savile strikes bizarre poses for a bank of press photographers, Savile is presented as a performative, highly visible but unknowable figure. The editing of the archival materials (using dissolves, wipes, flares and morphing) and the use of the rostrum camera to mobilise still photographs (zooming in and out, travelling across their surface) renders the images unstable. As the sequence progresses, the use of less easily contextualised images heightens the sense of unease. What are we to make of a photograph of a youthful Savile in bed, naked from the waist up, smoking a cigar, holding a cup of tea and looking directly at the camera?

Importantly, however, this sequence - whilst unsettling - largely uses images from Savile's heyday in which, despite his sometimes outlandish dress, he less obviously embodies the 'monstrous other' which is encapsulated in the late-career images which come to dominate the news landscape in the months after the revelations. The late-career images tend to more obviously fit within the aesthetics of the monstrous which I referenced in the introduction: his flyaway hair unkempt, his stained and crooked teeth chomping on an 
oversized cigar, his rose-tinted glasses giving his face an unhealthy pallor, and his garish tracksuits often worn unfastened over a string vest. In contrast, the opening sequence of Exposure serves as a reminder of Savile's televisual history, his celebrity, and his association with some of the UK's biggest family entertainment shows - as well as his establishment links.

Kinetic scrutiny of the photographic image is a common feature of television documentary (Lury 2003), so this opening sequence is not unusual in this respect. However, the archival footage is intercut with interview clips from Savile's (still anonymous) victims which trail the documentary's most serious allegations. Two of the victim/survivors are heavily disguised to protect their identity, and those who are not are filmed by static cameras in medium closeups in domestic settings. This is, then, a juxtaposition of modes of television: the deceptive and explicitly performative light entertainment associated with Savile in his heyday, versus the formal simplicity of documentary authenticity allied to his accusers. It is also a juxtaposition of modes of being on television: celebrity performer, versus 'ordinary' person.

In Exposure, the archival footage bears witness to the context the women describe as well as, sometimes, providing corroboration (e.g. that they attended a recording at Television Centre). Yet, the status of archival footage is simultaneously in question as the scandal quickly becomes understood as a crisis in representation. The same clips that establish victim/survivor reliability demonstrate Savile's skills in deception and manipulation. The intercutting of contemporary interviews with both archival footage and reconstructions is common across a number of the documentaries. (11) Reconstructions provide visual anchors which further situate the testimony historically (e.g. through the use of period detail such as furnishings and fashions) or spatially (e.g reconstructions of off-screen areas at the $\mathrm{BBC}$ ). These reconstructions are clearly marked - for example, through highly saturated colour and a grainy effect (in Exposure) or the use of canted angles (in After Savile) - and the formal contrasts help to highlight the gaps in the archive and, indeed, the equally constructed nature of those clips. Again, the contrast with the formal simplicity and muted colours of the interviews is striking.

One of the ways the changing status of the archival footage is signalled over time is through disguising (some) members of the public who appear with Savile. That these are aesthetic and ethical choices rather than editorial requirements is highlighted as much of the same footage is used in different ways. For instance, in Exposure, 'Fiona' recounts how Savile lured and coerced the vulnerable young women at Duncroft Approved School with the promise of attending television recordings. A clip from Savile's early 1970s' variety show Clunk Click anchors this part of Fiona's testimony. It shows Savile and glam rock star Gary Glitter interacting with the female audience: audience members are visible and identifiable. The clip ends with Savile sitting between two young women. As he locks his arms around their necks, they laugh but look surprised, nervous and uncomfortable.

The same clip is used, less than three weeks later, in the BBC's first documentary response to the case - What the $B B C$ Knew. The emphasis of this documentary is very different: an investigation by the $\mathrm{BBC}$ into the $\mathrm{BBC}$, it focuses on the decision to shelve the Newsnight investigation, rather than on the allegations per se. Here, Clunk Click is used in conjunction with victim/survivor Karin Ward's testimony, originally filmed for Newsnight and shown 
here for the first time. Presenter Shelley Jofre's voiceover details how Savile would invite girls from Broadmoor secure hospital to the recording of his shows. Unlike in Exposure (where this footage anchors Fiona's story about Duncroft), here the identities of all audience members are disguised, with contradictory effects. The sense of unease visible in the women's faces is lost, whilst Savile himself remains front and centre. Moreover, it is unclear whether their identities are concealed to protect audience members from association with the secure hospital or with Savile. The Clunk Click footage with Glitter crops up again in the much later Louis Theroux: Savile but in Theroux's documentary the audience members are again identifiable.

Tellingly, other clips used in What the BBC Knew - including one from Savile's Travels in which he laughingly gropes a young woman - do not disguise the identities of adult audience members. In contrast, children appearing on Jim'll Fix It are disguised. The effect of this is to mark - and render suspect - Savile's interactions with young audiences, whilst his groping of and leering at adult women is recirculated, unedited. These examples underline my point that these are aesthetic and ethical decisions, whilst also highlighting the repetition and revision of archival material across the documentaries. These decisions, in different ways, position victim/survivors in the archive whilst - in the later documentaries in particular renegotiating Savile's televisual presence, as we will now see.

\section{(In)visible, (un)speakable: televising testimonies}

Abused: The Untold Story was broadcast after Dame Janet Smith (2016) delivered her final report on Savile at the BBC. In Abused it is patently clear that Savile has become a toxic presence for the BBC. Echoing Aust and Holdsworth's (2017) discussion of the BBC's attempts to exorcise Savile from its archive-in-circulation, and Aust's (2018) more recent work on the BBC's online archive, clips from his flagship shows are used sparingly and are edited so that Savile is barely visible. In the clips in which he is visible, all 'ordinary' people on-screen - audience members, show participants, bystanders - are disguised, underlining the extent to which the modality of this footage is now in doubt: the programme makers can no longer be sure what this footage means, what it reveals and what is conceals.

However, this needs to be understood not simply in relation to Savile's toxicity, but also the victims'/survivors' increased presence. This is not to say that all the documentaries privilege filmed victim/survivor testimony - they do not - but to note that assumed viewer knowledge and acceptance of this testimony is increasingly the context in which they operate. For instance, Savile: The Power to Abuse makes very limited use of filmed testimonies, focusing instead on institutional knowledge and complicity. However, in contributions from the presenter and other commentators, victim/survivor testimony is continually referenced and its veracity accepted. Thus the new filmed testimonies which are used are understood to be snapshots of a much broader story. Similarly, all the documentaries mention how many victim/survivors have come forward at different stages in the investigation or refer to official reports and complaints.

Building on Amy Holdsworth's (2011) work on the interplay of remembering and forgetting on television more broadly, I want to argue that Savile is only able to be - visually if not 
thematically - 'forgotten' once his accusers' memories have themselves become part of television's archive. Karin/Kat Ward (13) is a significant figure in this. Ward was the first to discuss her experiences of abuse on camera, for Newsnight. Her testimony also implicated Gary Glitter and detailed how Savile would invite girls from Duncroft- where Ward was a pupil - to Television Centre for recordings of his shows. Ward gave the interview to Newsnight just before undergoing major surgery and was not subsequently part of Exposure. However, once the story broke, she was widely interviewed on television and in print media. The Newsnight footage was eventually used in What the BBC Knew and clips from Ward's 2011 interview have been widely used since. New interviews with Ward are used in What the BBC Knew, Abused and Louis Theroux: Savile and Ward has published her own account of the case, Victim Zero (2016).

By the time Ward first appeared on television, then, her story was as much about the difficulties for victim/survivors of speaking out on (and in relation to) television as about her experiences of abuse. Due to the circumstances in which Ward's story was finally told, it was publicly heard as an echo of other testimonies, even though those testimonies were themselves a response to knowledge of her (then unbroadcast) Newsnight interview. This is interesting not only as a form of corroboration, but also in terms of television's selfreferentiality, enhancing the sense that history on television is history as-previously(shown)-on-television (Holdsworth, 2011). Although Newsnight's failure to show Ward's interview is at the heart of What the BBC Knew, the 2011 footage is nonetheless diegetically marked as television history. The date of the recording appears in the top left of the frame and clips from her interview are refilmed on a screen, to create a pixelated, blurred effect. This effect is also used for clips from Exposure and from a news conference given by the then BBC Director General. Ward's interview is therefore allied with broadcast television and the inferior quality of the image becomes a mark both of authenticity and televisuality, creating striking juxtapositions with the 'clean' (but deceptive) light entertainment archive.

The day before Exposure (and before Ward's first broadcast interview), Dee Coles became the first woman to be shown on television identifying Savile as a rapist. Coles contacted ITN after she heard news reports about the allegations against Savile. Coles was 14 years old and on holiday in Jersey when Savile raped her. As such, the televisual possibilities presented by Coles' story - which, like Ward's, has now been repeated and revisited in multiple contexts -are different. It is personal photographs of Coles with Savile (rather than archival television) that both corroborate Coles' story (she was there) and simultaneously highlight the problematic nature of representation (she is smiling).

Tracing the use of these photographs over time points to Coles' and Savile's changing positions in the television narratives of the case. The ITN interview begins with an unseen Coles describing the context in which the Polaroid photographs were taken. As Coles speaks, the camera probes the photographs for their evidentiary function: arranging them in sequence, zooming in and out. We then cut to a medium shot of Coles with reporter Lucy Manning, Coles handling the photographs as she details how Savile abused her. That these images were previous unseen and privately owned is part of what renders them authentic and news at this stage. Again, the juxtaposition with archival footage of Savile is significant. Here, he shown on an elevated stage at an outdoor function, surrounded by an apparently appreciative audience. Although Coles is not in this footage, it nevertheless serves a similar 
evidentiary function to the Clunk Click clips: it places Savile at the scene of the crime (Jersey in the 1960s) whilst also supporting Coles' reasoning for not coming forward, the low camera angle emphasising Savile's power whilst the exuberance of the scene underscores his popularity. Coles asks: 'who would have believed me?'

Coles' personal photographs are also used in the much later Abused and Crimewatch Special. In these later programmes, the status of the photographs has shifted: they have become television, referencing earlier stages in the development of the story as much as they reference Coles' experiences. In keeping with the visual reorientation of the story across the intervening three-and-a-half years, in Abused the camera zooms in on the photograph so that Coles is centred and Savile is out of frame. Coles' photographs are not the only evidence revisited in this way in Abused. Footage from Kevin Cook's appearance on Jim'll Fix It is edited similarly, cropping Savile from the frame and centring the young Cook. In this way, Abused becomes a commentary on - and intervention in - representational practices around the celebrity-abuser, rejecting his centrality and asserting the importance of victim/survivors.

In Catching the Abusers, Coles is one of many survivors addressing an audience of other survivors, encouraging them to come forward. Savile, initially unnamed, is one of many male perpetrators, no longer 'special'. The clip of Top of the Pops which follows begins with the programme's familiar countdown graphics and a black-and-white close-up of Savile. There is a freeze-frame on a smiling Savile, and the screen fades briefly to black before titles, accompanied by discordant music, recontextualise this television history and lead us to a new interview with Coles. Coles' testimony is intercut with the now-familiar photographs, the camera zooming in and out to allow us to pick out details in her testimony. Here the photographs are investigated not because Coles' smiling face conceals what is going on, but for what they reveal about the interaction: Savile's leg pressed between hers; his naked torso. As in Abused, this treatment of the photographs keeps them at a distance from Coles, and the distinctive white border that marked them as Polaroids has been cropped. No longer the material objects Coles kept as 'evidence', they are now part of a public, distinctly televisual history.

Through this process, a problematic televisual history is set alongside a redemptive one as the documentaries both narratively and formally reference television's role in exposing Savile. This is reinforced through the repeated use of Ward and Coles - the two women who can, in different ways, lay claim to being 'victim zero' in the Savile case - along with a number of other victim/survivors, including Kevin Cook (mentioned above). It is right to be sceptical of the self-serving nature of this coverage for the BBC in particular, and there are questions to be asked about whether returning to the same victim/survivors keeps them perpetually trapped in Savile's shadow. However, the relatively long duration of television engagement with the case - and with these victim/survivors - has allowed for an unusual level of detail to emerge about their lives, reorienting the story from a focus on the celebrity abuser, to think about what the abuse meant in the lives of victim/survivors. For instance, in Theroux's 2016 documentary Ward testifies to being abused by her stepfather and his friends (also Ward, 2016). Indeed, Ward is not the only victim/survivor of Savile whose later interviews reveal a continuum of abuse by adult men across their childhoods (and sometimes beyond): Sam - another victim/survivor of Savile, interviewed in both Abused 
and Louis Theroux; Savile tells a similar story. Although this does not dislodge the paedophile frame, it is at least an acknowledgement that paedophiles aren't just outlandish celebrities but can be found much closer to home.

Moreover, the later interviews provide the women with a (limited) opportunity to 'talk back' to (and on) television about how their stories have been told. For example, in Abused, Coles notes that she took medication prior to her ITN interview to enable her to get through it, but that this produced a calm, affectless performance which minimised the ongoing effects of the abuse. Interestingly, the qualities Coles highlights as 'inauthetic' to her lived experience are those that Newsnight interviewer Liz MacKean (in What the BBC Knew) and television presenter and campaigner Esther Rantzen (in Exposure) identify as markers of authenticity, highlighting the double-bind for survivors around appropriate, 'authentic' selfpresentation.

Tracing some of the differences in representation across these women's (and men's) testimonies allows us to see their constructed nature. This is not to cast doubt on the veracity of their stories, but rather - in keeping with other scholarship on trauma and documentary (Torchin, 2012; Shenkler, 2010; Walker, 2005), as well as on television and memory (Holdsworth, 2011) - to explore the ways in which trauma is rendered accessible and authentic (or not). Central to my argument here is that it is not only the collective weight of testimonies which is significant in the Savile case, but also the ways in which through repetition and revision - they become televisual history.

Indeed, as the number of victim/survivors mounted, the formal strategies for representing testimony became another source of corroboration, rendering Savile himself redundant and allowing for connections to be made with other perpetrators. Abused is notable in this respect as it includes testimony from women and men abused by Savile and his associates, alongside testimony from Katy, a victim/survivor of abuse by a man known to her but never to the television audience. Although Katy's story is not directly linked to Savile (her abuser was a family acquaintance), she was encouraged to come forward by the increased visibility given to child sexual abuse post-Savile. Katy's story could not have functioned in the same way in earlier documentaries where Savile was such a strong visual presence: after all, her abuser remains invisible. Her testimony is anchored instead to the televisual testimonies of other victims. Similar set-ups are used for interviews with all victims/survivors in Abused: domestic spaces in which the victim/survivor and, in many instances, a close supporter (usually their spouse) are positioned at opposite ends of a table or sofa, facing the camera. This is interspersed with more intimate medium close-ups of victim/survivors, the 'talking heads' which dominate the other documentaries and are more broadly favoured in audiovisual testimonies as a means to establish intimacy without becoming intrusive (Shenker, 2010).

To the extent that these stories were allowed to unfold televisually over more than four years they well illustrate the enduring impact of child sexual abuse in the lives of victims/survivors: their testimony is not a one-off incident but repeated - either by themselves or in echoes in the other victim/survivor accounts now part of television's archive. Audiences would not need to have extensive knowledge of the case to appreciate this, as the later documentaries use archival footage of the Savile case and create other 
echoes and repetitions in the staging of new interviews. Of course, Savile has not disappeared - he remains a visible presence in news and documentaries - but the recontextualisation of archival material has largely changed its modality: from light entertainment to crime scene.

\section{Conclusion}

The documentaries which followed Savile's unmasking as a serial sexual predator in Exposure quickly accepted the veracity of the allegations against him, constructing a new archive of televisual testimony which itself became a thematic and formal reference point for new revelations. This was achieved through the self-referentiality of the documentaries, the multiplication of similar (and similarly staged) testimonies, the use of a number of interviews in multiple contexts and repetition of some testimonial footage, and the interrogation and revision of more well-known archival materials. This is a welcome development, providing a corrective to the decades-long failure to recognise the abuse which lurked at the edges of the BBC's light entertainment content and archive.

With a number of Savile's victims commenting (in official reports as well as in television news and documentaries) on how Savile's prior ubiquity increased their sense of powerlessness and inability to speak out, the ethical issues around the re-use of archival footage of the celebrity abuser cannot be easily dismissed (also Wheatley, 2017). However, this article has demonstrated changes in the use of this footage over time which have allowed for victim/survivor testimonies to be contextualised in different ways. In early coverage, archival footage functioned as corroboration of victim/survivor testimony as well as an explanation for prior silence. In later coverage, the visual reorientation towards victims demonstrated changing understandings of the crimes and the role of television in both covering them up and revealing them. Whilst the televisual re-centring on victim/survivors is to be broadly welcomed, there is nevertheless a danger that a wholesale expunging of Savile from television (and television history) renders his crimes less comprehensible to future generations, whilst also increasing the expectation on victim/survivors.

Although similar issues are raised by the Weinstein moment, there are important differences, not least in terms of the notions of cultural value which continue to afford a protection to film as 'art' but rarely to light-entertainment television. Yet, this does not mean that viewer investment in Savile and his output was negligible, and one final example speaks to this. In his 2016 Savile documentary, Louis Theroux interviews Sylvia Nicol who worked at Stoke Mandeville Hospital, one of the charitable causes with which Savile was most closely aligned. Whilst she does not explicitly reject the veracity of victim/survivor testimonies, Nicol nevertheless struggles to reconcile what she knew of Savile with what has become the dominant narrative about him:

Nicol: I'm a victim, his family are victims. As much as anybody else would be a victim. Theroux: Who or what are you a victim of.

Nicol: I'm a victim of losing those memories, and that is quite a big thing out of your life, because when you get older your memories ... do become more important. And 
that was many years of memories. He wasn't a friend to me, he was a friend to what I'd spent 50 years of my life with which was the spinal centre, and we wouldn't have a spinal centre there now but for Jimmy. Which would mean we wouldn't have a lot of people alive now.

Whilst Nicol's claim of victimisation grates next to those of the women Savile raped and sexually abused (14), nonetheless, I want to take her statement seriously. What role might the television archive play in preserving those memories, whilst simultaneously disrupting them? As I have argued, Savile's respectability and ubiquity in his lifetime are an essential part of this story, explaining why victim/survivors were unable to come forward earlier. If we lose sight of this, simply re-constructing Savile as that monstrous-other par excellence, the paeodphile (Kitzinger, 1999; Kelly, 1996), then there is a danger that we forget the cultural conditions which enabled Savile to get away with abusing women, girls and boys for decades - conditions which find a contemporary echo in the Weinstein case.

I have argued elsewhere (Boyle, 2017) that Savile's sexist and sexualized behavior towards adult women was an alibi which allowed his criminally abusive behavior to pass unremarked in many contexts. Doing 'good' was another, as was insulating himself through his links to establishment figures and institutions (Cross, forthcoming). As such, the value of Savile's presence in the television archive is not simply to help us identify 'dog whistle' (Cross, 2016) moments where viewers and programme makers could and should have known: important as this is. The archive can also help us to understand why many did not know and (like Nicol) struggle to reconcile their own memories of Savile (on television and in life) with the version which has emerged since his death.

That we now have so many commentaries from victim/survivors of Savile provides an important counter-narrative which has a televisual history of its own. These are as unusual as they are essential, but they also point to some of the ways in which by connecting victim/survivors' experiences (formally as well as thematically) we can construct a more nuanced account of the continuum of sexual violence. This does not have to be achieved only through personal testimony: organisations working with victim/survivors can also serve this function without putting victim/survivors in the media spotlight. It is striking, and problematic, that organisations like Rape Crisis were not used in these documentaries, watering down the potential for political, feminist analysis. Yet, the sheer number of women and men accusing Savile meant that the media's tendency to personalise, individualise and sensationalise stories of child sexual abuse (Armstrong, 1996) was less evident here. Nevertheless, if we are genuinely to shift the way in which we deal with sexual violence, then perpetrators have to be held to account and making the continuum in their own behavior from 'everyday sexism' to rape - visible is one way of doing this (Boyle, 2018). Where perpetrators have historically enjoyed more visibility than victim/survivors (as in cases involving celebrity perpetrators), this involves a re-analysis of the ways in which they have been represented. This is not simply an academic or activist practice, but can also involve mainstream media texts. It may involve (temporary?) erasure, but it should more fruitfully involve recontextualisation and recentering - something many of the documentaries discussed in this article have done successfully. Part of what is at stake in these recontextualisations is television history itself. The Savile case has exposed the necessity of considering what television's representational practices and institutional cultures have 
disguised, but a wholesale expunging of Savile's position within that televisual history is not only potentially self-serving for the BBC (Aust, 20018) but - as I have suggested - would also render victim/survivor testimony incomprehensible in important ways. Television was part of the problem in the Savile case for sure. But this article suggests that television may also contribute towards finding solutions and new ways of telling these stories.

\section{Notes}

(1) Thompson's interview with Newsnight (BBC, 12 October 2017) can be viewed at: https://www.youtube.com/watch?v=XV W6kPqR9U (accessed 5 November 2017).

(2) Brand was responding to an all-male panel belittling reports of sexual harassment in the Westminster Parliament: https://www.theguardian.com/uk-news/video/2017/nov/04/jobrands-speech-on-sexual-harassment-silences-all-male-panel-on-have-i-got-news-for-youvideo (accessed 5 November 2017).

(3) Burke's account of the origins of the \#MeToo movement can be read here: (http://justbeinc.wixsite.com/justbeinc/the-me-too-movement-cmml) (accessed 5 November 2017).

(4) Based on a Nexis search for Harvey Weinstein AND Jimmy Savile in the month after the Weinstein story broke (5 October -5 November 2017). New allegations against BBC talent (George Riley and Chris Evans) in the wake of Weinstein were the only other stories to refer back to Savile.

(5) There have been more than 40 National Health Service/ Department of Health reports into Savile's activities within different hospitals (https://www.gov.uk/government/collections/nhs-and-department-of-healthinvestigations-into-jimmy-savile ) as well as reports by the Independent Police Complaints Commission (https://www.ipcc.gov.uk/investigations/jimmy-savile-west-yorkshire-policesurrey-police-sussex-police-and-north-yorkshire).

(6) The BBC broadcast three television tributes: Sir Jimmy Savile: As It Happened (BBC1, 11 November); Jim'll Fix It With Shane Ritchie (BBC1, 26 December); and Sir Jimmy Savile at the BBC: How's About That Then (BBC2, 28 December); and a Christmas Day Radio 2 tribute, Sir Jimmy Savile: In His Own Words.

(7) Documentaries include: Britain's Sex Gangs (Channel 4, 7 November 2011), Britain's Hidden Child Abuse (Channel 4, 30 January 2013), The Hunt for Britain's Sex Gangs (Channel 4, 23 May 2013), The Paedophile MP (Channel 4, 12 September 2013), Predators Abroad (ITV, 2 October 2013), Stolen Childhoods - The Grooming Scandal (1 September 2014), The Legacy of Grooming (29 June 2015), The VIP Paedophile Ring (BBC1, 6 October 2015), The Truth About Child Sexual Abuse (BBC2, 24 November 2015), Football Abuse: The Ugly Side of the Beautiful Game (BBC1, 9 May 2017) and Abused and Betrayed (ITV, 15 June 2016).

(8) Including critically-acclaimed dramas National Treasure (Channel 4, October 2016) and Three Girls (BBC1, May 2017) and a grooming storyline in Coronation Street (ITV, 1960-).

(9) Similar arguments have been made about both press coverage of (Boyle, 2017), and official reports into (Westmarland, 2015: 154), Savile's offending.

(10) There was a $60 \%$ increase in child sexual abuse reported to the police from 2011-2015 with a $81 \%$ increase in calls about sexual abuse to the NSPCC helpline in the year after the launch of the Operation Yewtree investigation into non-recent abuses by Savile and others (Travis, 2015). Non-recent cases continue to be inadequately reflected in police statistics which record the age at the time of the incident but not the time of reporting (Rape Crisis 
England and Wales, 2015). Nevertheless, figures from Rape Crisis in England and Wales (https://rapecrisis.org.uk/statistics.php), and Scotland

(https://www.rapecrisisscotland.org.uk/publications/?cat=1), demonstrate that around three-quarters of all adult service users now contact Rape Crisis about sexual violence that occurred at least 12 months ago, with significant proportions reporting abuse from more than 20 years ago. This makes the invisibility of Rape Crisis in news and documentaries on the Savile case all the more striking.

(11) Exposure, What the BBC Knew, Exposure Update, After Savile and Britain's Worst Crimes all use reconstructions.

(12) Glitter was convicted of child pornography offences in 1999 and, by the time of Exposure, had been banned from Cambodia for suspected child sexual abuse and convicted of obscene acts with girls aged 10 and 11 in Vietnam. After his release he returned to the UK and, in the aftermath of Savile, was found guilty of a series of child sex offences on girls aged 8-13 and sentenced to 16 years (McVeigh, 2015).

(13) Ward is identified as Karin in the Newsnight interview and most subsequent appearances. In Theroux's documentary she is introduced as Kat and this is the name she publishes under.

(14) As I have argued elsewhere (Boyle, 2016), Louis Theroux: Savile is problematic for the onus it places on women (victim/survivors and supporters) to explain Savile's behaviour and legacy, meaning it stops short of its stated intent to examine Theroux's own complicity as Savile's friend and documentarist.

\section{References}

Armstrong L (1996) Rocking the Cradle of Sexual Politics: What Happened When Women Said Incest. London: Women's Press.

Aust R (2018) Jimmy Savile and the BBC archive: Re-writing the history of the corporation. Paper presented at Society for Cinema and Media Studies Conference, Toronto, 14 March 2018.

Aust R and Holdsworth A (2017) The BBC archive post-Jimmy Savile. In: Kay JB, Mahoney C and Shaw C (eds) The Past in Visual Culture: Essays on Memory, Nostalgia and the Media. Jefferson: MacFarland, pp. 170-184.

Author (2009) Gendered narratives of child sexual abuse in fiction film. In: Cuklanz LM and Moorti S (eds) Local Violence, Global Media: Feminist Analyses of Gendered Representations. New York: Peter Lang, pp.181-200.

Bates L (2014) Everyday Sexism. London: Simon \& Schuster.

Boyle K (2005) Media and Violence: Gendering the Debate, London: Sage.

Boyle K (2016) Louis Theroux's new Jimmy Savile documentary is a horrible misstep. The Converstion, 3 October. Available at: https://theconversation.com/louis-therouxsnew-jimmy-savile-documentary-is-a-horrible-misstep-66421 (accessed, 4 December 2017).

Boyle K (2017) Hiding in plain sight: Gender, sexism and press coverage of the Jimmy Savile case. Journalism Studies (online first, 3 February 2017).

Boyle K (2018) What's in a name? Theorising the inter-relationships of gender and violence. Feminist Theory, 20 (2). Online first: 20 February 2018. DOI: $10.1177 / 1464700118754957$. 
Brison S (2003) Aftermath: Violence and the Remaking of a Self. Princeton: Princeton University Press.

Brooks X (2017) Reel dilemma: Are we condoning the conduct of Hollywood's tyrants by watching their films? The Guardian, 10 November. Available at:

https://www.theguardian.com/film/2017/nov/10/reel-dilemma-are-we-condoningthe-behaviour-of-hollywoods-tyrants-by-watching-their-films- (accessed 14

November 2017).

Crimewatch (1984-2017) BBC1.

Cross S (2016) Disclosure and enclosure: Revisiting media profiles of Jimmy Savile. In: Joseph S and Keeble RL (eds) Profile Pieces: Journalism and the 'Human Interest' Bias. London: Routledge, pp. 100-115.

Cross $S$ (forthcoming) Friends in high places: Sexual abuse, power, and the corruptions of Jimmy Savile. In: Ewen N, Grattan A, Leaning M and Manning P (eds) Capitalism, Crime and Media in the $21^{\text {st }}$ Century. Basingstoke: Palgrave Macmillan.

Davies D (2014) In Plain Sight: The Life and Lies of Jimmy Savile. London: Quercus.

Exposure (2011) ITV. ITV Studios et al.

Furedi F (2013) Moral Crusades in an Age of Mistrust: The Jimmy Savile Scandal. Basingstoke: Palgrave Macmillan.

Furedi F (2015) The moral crusade against paedophilia. In: Smith M (ed) Moral Regulation. Bristol: Policy Press, pp.7-18.

Greer C and McLaughlin E (2013) The Sir Jimmy Savile scandal: Child sexual abuse and institutional denial at the BBC. Crime, Media, Culture 9(3): 243-263.

Greer C and McLaughlin E (2015) The return of the repressed: Secrets, lies, denial and historical institutional child sexual abuse scandals. In: Whyte D (ed) How Corrupt is Britain? London: Pluto, pp. 113-23.

Hardie K (2017) Time to make the link between abuse and film content: Men continue to hold the power over how women's bodies are portrayed on screen. The Guardian, 15 October. Available at:

https://www.theguardian.com/commentisfree/2017/oct/14/time-to-make-linkbetween-abuse-and-film-content (accessed 6 November 2017)

Have I Got News For You (1990-) BBC. Hat Trick Productions.

Holdsworth A (2011) Television, Memory and Nostalgia. Basingstoke: Palgrave Macmillan. Jordan J (2011) Silencing rape, silencing women. In: Brown J and Walklate S (eds) Handbook on Sexual Violence. London: Routledge, pp. 80-313.

Jordan J (2013) From victim to survivor - and from survivor to victim : Reconceptualising the survivor journey. Sexual Abuse in Australia and New Zealand, 5(December): 48-56.

Kantor J and Twohey M (2017) Harvey Weinstein paid off sexual harassment accusers for decades. The New York Times, 5 October. Available at:

https://www.nytimes.com/2017/10/05/us/harvey-weinstein-harassmentallegations.html (accessed 6 November 2017).

Kelly L (1988) Surviving Sexual Violence. Cambridge: Polity.

Kelly $L$ (1996) Weasel words: Paedophiles and the cycle of abuse. Trouble and Strife 33.

Available at: http://www.troubleandstrife.org/articles/issue-33/weasel-wordspaedophiles-and-the-cycle-of-abuse/ (accessed 20 July 2017)

Kelly L (2005) Fertile Fields: Trafficking in Persons in Central Asia Fertile Fields : Trafficking in Persons in Central Asia, Vienna: International Organization for Migration. 
Kelly L, Burton S and Regan L (1996) Beyond victim or survivor: Sexual violence, identity and feminist theory and practice. In: Adkins $L$ and Merchant V (eds), Sexualizing the Social: Power and the Organization of Sexuality. Basingstoke: Macmillan, pp. 77-101. Kitzinger J (1999) The ultimate neighbor from hell? The media representation of paedophilia. In: Crichter C (ed) (2006) Moral Panics and the Media: Critical Reading. Maidenhead: Open University Press, pp. 135-147.

Lury K (2003) Closeup: documentary aesthetics. Screen 44(1); 101-105.

McVeigh K (2015) Gary Glitter found guilty of child sex offences. The Guardian, 5 February. Availale at: https://www.theguardian.com/uk-news/2015/feb/05/gary-glitter-guiltychild-sex-offences (accessed 14 November 2017).

National Treasure (2016) Channel 4. Channel 4.

Newsnight (1980-) BBC2. BBC.

Parkinson HJ (2017) Kevin Spacey deserves to be scorned. But can I still watch House of Cards? The Guardian, 2 November. Available at: https://www.theguardian.com/commentisfree/2017/nov/02/kevin-spaceydeserves-scorned-watch-house-of-cards (accessed 6 November 2017).

Pollard, Nick. 2012, December 18. The Pollard Review: Report. http://downloads.bbc.co.uk/bbctrust/assets/files/pdf/our work/pollard review/poll ard review.pdf (accessed 20 July 2017).

Shenker N (2010) Embodied memory: the institutional mediation of survivor testimony in the United States Holocaust museum. In Sarkar B and Walker J (eds) Documentary Testimonies: Global Archives of Suffering. New York: Routledge, pp.35-58.

Silverstein M (2017) Other stories: Why now is the time for a new movie canon - chosen by women. The Guardian, 3 November. Available at:

https://www.theguardian.com/film/2017/nov/03/other-stories-why-now-is-thetime-for-a-new-movie-canon-chosen-by-women (accessed 6 November 2017).

Smith J (2016) The Dame Janet Smith Review Report: Volume 2 - The Jimmy Savile Investigation Report. London: BBC, February.

http://www.bbc.co.uk/bbctrust/dame janet_smith (accessed 20 July 2017).

Three Girls (2017). BBC1. BBC Studios/ Studio Lambert.

Top of the Pops (1964-2006). BBC1. BBC.

Torchin L (2012) Creating the Witness: Documenting Genocide on Film, Video, and the Internet. Minneapolis: University of Minnesota Press.

Travis A (2015) Reported child sexual abuse has risen 60\% in last four years, figures show. Guardian 9 April. Available at: https://www.theguardian.com/society/2015/apr/09/reported-child-sexual-abusehas-risen-60-in-last-four-years-figures-show (accessed 20 July 2017).

Walker J (2005) Trauma Cinema: Documenting Incest and the Holocaust. Berkeley: University of California Press.

Ward K (2016) Victim Zero: Jimmy Savile Tried to Runi my Life. I Was the First Victim to Fight Back. London: John Blake Publishing.

Wheatley $\mathrm{H}$ (2017) Haunted television: trauma and the spectre in the archive. Paper presented at Screen Studies Conference, University of Glasgow, 24 June 2017. 